\title{
Neonatal systemic juvenile Xanthogranuloma with Hydrops diagnosed by Purpura skin biopsy: a case report and literature review
}

Yohji Uehara ${ }^{1}$, Yuka Sano Wada ${ }^{1 *}$ D, Yuka Iwasaki ${ }^{1}$, Kota Yoneda', Yasuhisa Ikuta', Shoichiro Amari ${ }^{1}$, Hidehiko Maruyama', Keiko Tsukamoto', Tetsuya Isayama', Kenichi Sakamoto², Yoko Shioda², Osamu Miyazaki Rie Irie ${ }^{4,5}$, Takako Yoshioka ${ }^{4}$, Naoko Mochimaru ${ }^{6}$, Kazue Yoshida ${ }^{6}$ and Yushi Ito ${ }^{1}$

\begin{abstract}
Background: Systemic juvenile xanthogranuloma is a very rare disease typically presents as skin lesions with yellow papules or nodules and is sometimes fatal. We report a case of congenital neonatal systemic juvenile xanthogranuloma with atypical skin appearance that made the diagnosis difficult.

Case presentation: A preterm Japanese female neonate with prenatally diagnosed fetal hydrops in-utero was born with purpuric lesions involving the trunk and face. Since birth, she had hypoxemic respiratory failure, splenomegaly, anemia, thrombocytopenia, coagulopathy, and was transfusion dependent for red blood cells, fresh frozen plasma, and platelets. Multiple cystic lesions in her liver, part of them with vascular, were detected by ultrasound. A liver biopsy was inconclusive. A skin lesion on her face similar to purpura gradually changed to a firm and solid enlarged non-yellow nodule. Technically, the typical finding on skin biopsy would have been histiocytic infiltration (without Touton Giant cells) and immunohistochemistry results which then would be consistent with a diagnosis of systemic juvenile xanthogranuloma, and chemotherapy improved her general condition.
\end{abstract}

Conclusions: This case report shows that skin biopsies are necessary to detect neonatal systemic juvenile xanthogranuloma when there are organ symptoms and skin eruption, even if the skin lesion does not have a typical appearance of yellow papules or nodules.

Keywords: Systemic juvenile xanthogranuloma, Purpura, Skin biopsy, Neonate, Fetal hydrops

\section{Background}

Juvenile xanthogranuloma (JXG) is a rare benign histiocytic disorder with solitary or multiple skin lesions that present as yellow papules or nodules, which typically appear in the first year of life and are self-limiting [1-4].

\footnotetext{
* Correspondence: wada-y@ncchd.go.jp

'Department of Neonatology, Center for Maternal-Fetal, Neonatal and Reproductive Medicine, National Center for Child Health and Development, 2-10-1 Okura, Setagaya-ku, Tokyo 157-8535, Japan

Full list of author information is available at the end of the article
}

JXG can be easily suspected from the yellow papules or nodules, and diagnosis is confirmed by biopsy. Systemic JXG is a very rare disease defined as the involvement of one or more visceral organs and is sometimes fatal [2, 4]. Its symptoms depend on the affected organ and include pancytopenia, anemia, thrombocytopenia, coagulopathy, cyanosis, cholestatic liver failure, hepatosplenomegaly, and seizure $[1,4-6]$. The mortality rate for JXG is especially increased in cases of liver and/or central nervous system infiltration $[2,5-7]$. Early diagnosis and treatment are therefore

(c) The Author(s). 2021 Open Access This article is licensed under a Creative Commons Attribution 4.0 International License, which permits use, sharing, adaptation, distribution and reproduction in any medium or format, as long as you give appropriate credit to the original author(s) and the source, provide a link to the Creative Commons licence, and indicate if changes were made. The images or other third party material in this article are included in the article's Creative Commons licence, unless indicated otherwise in a credit line to the material. If material is not included in the article's Creative Commons licence and your intended use is not permitted by statutory regulation or exceeds the permitted use, you will need to obtain permission directly from the copyright holder. To view a copy of this licence, visit http://creativecommons.org/licenses/by/4.0/ The Creative Commons Public Domain Dedication waiver (http://creativecommons.org/publicdomain/zero/1.0/) applies to the data made available in this article, unless otherwise stated in a credit line to the data. 
important. Systemic JXG is also easily suspected from the yellow papule or nodule appearance. We report a case of congenital neonatal systemic JXG that was difficult to diagnose due to the atypical appearance of a purple skin rash.

\section{Case presentation}

A Japanese female neonate was born by emergency cesarean section at 34 weeks of gestational age despite an uneventful prenatal course. Prenatal ultrasound (US) detected fetal hydrops and a higher middle cerebral artery peak systolic velocity $(85 \mathrm{~cm} / \mathrm{s} ; 1.7$ times that of the median, which was characteristic of severe fetal anemia) just before birth. The patient had a birth weight of 2362 $\mathrm{g}(+0.6 \mathrm{SD})$ and required mechanical ventilation immediately after birth due to hypoxemic respiratory failure. She presented severe anasarca edema, which was prominent on her trunk and face, pleural effusion and purpura on her body that included her face (Fig. 1a). She required mechanical ventilation for 52 days. Inotropes and parenteral nutrition were administered for 3 and 34 days, respectively. US showed ascites and splenomegaly but no other abnormal findings. An initial complete blood count indicated a hemoglobin level of $5.4 \mathrm{~g} / \mathrm{dL}$ and a platelet count of $6 \times 10^{3} / \mu \mathrm{L}$. The patient was coagulopathic and required daily blood transfusions (antithrombin, $13.4 \%$; D-dimer, $9.5 \mu \mathrm{g} / \mathrm{mL}$; fibrin/fibrinogen degradation products, $16.6 \mu \mathrm{g} / \mathrm{mL}$; the prothrombin time-international normalized ratio, activated partial thromboplastin time, and fibrinogen level were severely prolonged beyond the measurement range). With a suspicion of a hemolytic anemia or congenital infection, a Coombs test, blood, urine, and cerebral spinal fluid cultures and serologic testing for toxoplasmosis, hepatitis B, hepatitis C, syphilis, parvovirus B-19, rubella, cytomegalovirus, and herpes simplex virus, as well as polymerase chain reaction tests for varicella-zoster virus, Epstein-Barr virus, human herpesvirus 6/7, enterovirus, parechovirus, and adenovirus, were performed and results were negative. In addition, bone marrow aspiration was performed. But no leukemic blast and foamy macrophage were not seen. Thus, bone marrow aspiration also did not reveal an etiology.

The patient developed cholestasis and liver dysfunction with total bilirubin peaking at $30.5 \mathrm{mg} / \mathrm{dL}$ with a direct bilirubin of $21.7 \mathrm{mg} / \mathrm{dL}$, aspartate aminotransferase of $400 \mathrm{IU} / \mathrm{L}$, and alanine aminotransferase of $208 \mathrm{IU} /$ L. At 10 days of life, an US revealed multiple hypoechoic liver nodules and ascites along with splenomegaly but no hepatomegaly (Fig. 2). At 23 days of life, magnetic resonance imaging (MRI) assessment of these liver lesions demonstrated high T2 signal intensity and high diffusion-weighted images signal and low apparent diffusion coefficient signal, and these changes were nonspecific. Follow up US showed an increasing number of hypoechoic lesions with subsequent development of hepatosplenomegaly. Cardiac US, contrast-enhanced chest computed tomography, and brain MRI revealed no lesions in heart, lung and central nervous system.

An open liver biopsy conducted at 42 days of life showed giant hepatic cell transformation, cholestasis in hepatocytes, and foamy histiocytes accumulation with no infiltration into the portal region, which did not suggest typical systemic JXG, Langerhans cell histiocytosis, hepatoblastoma, or neuroblastoma. Due to a perceived change in one of the lesions from purpuric to a more firm and enlarged nodule (Fig. 1b), a skin biopsy was performed at 56 days of life. Immunohistochemistry demonstrated that the histiocytic population was CD68+, CD163+, CD1a-, and Langerin- (Fig. 3).

Chemotherapy based on the protocol for Langerhans cell histiocytosis in Japan [8] was started at 65 days of life. Induction therapy included cytarabine, vincristine, and prednisolone. The patient received prednisolone and low-dose cytarabine; however, vincristine was withheld due to hepatic dysfunction. The multiple hepatic nodules resolved on disappeared within four months after the
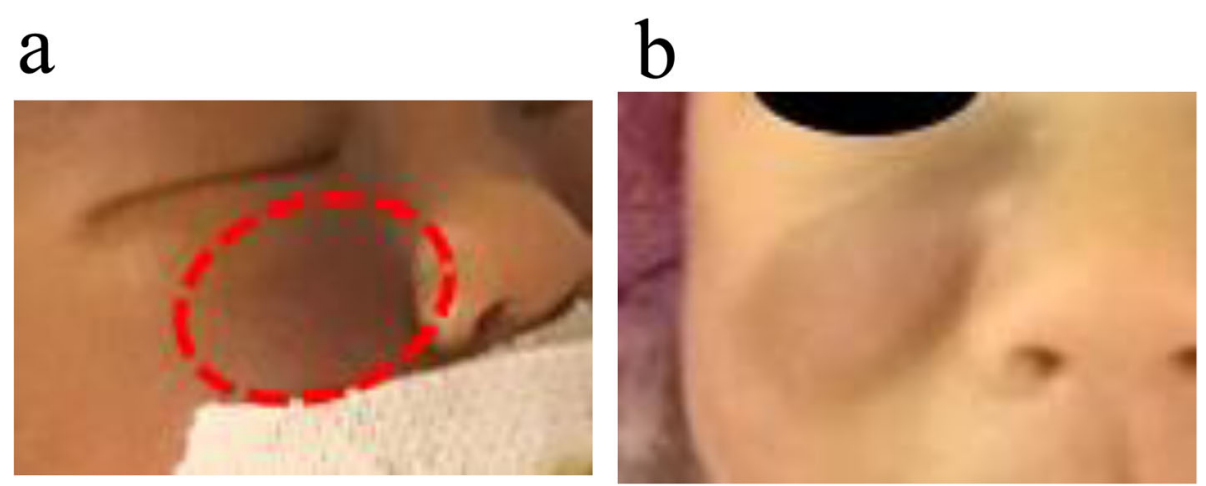

Fig. 1 a Purpura on her face at birth. b Purpura on her face at 56 days of life. The purpura changed to a firm and solid enlarged (but not yellow) nodule 


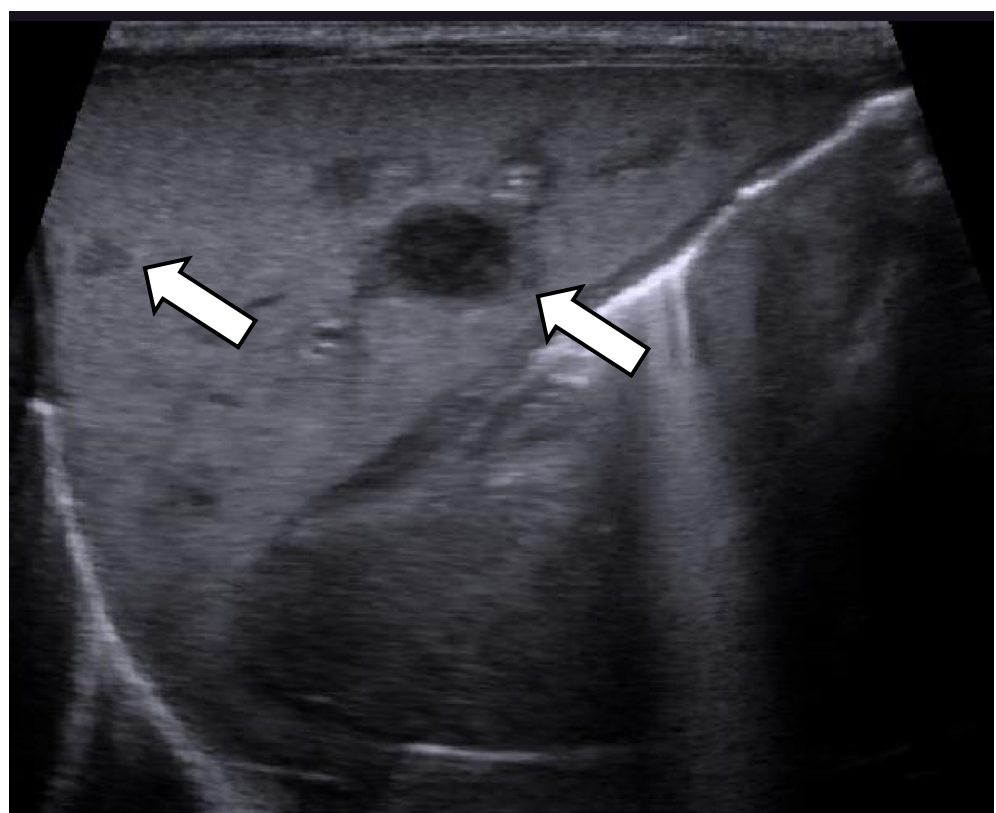

Fig. $\mathbf{2}$ US at 10 days of life. It revealed multiple hypoechoic liver nodules (arrow)

chemotherapy. The chemotherapy was continued for 54 weeks. The patient's neurodevelopment and weight gain at 24 months of life was satisfactory.

\section{Discussion and conclusions}

Making an immediate diagnosis of JXG was difficult because of the atypical appearance of the purple skin rash. At first, her purpuric skin lesions made believe that these were caused by coagulopathy. However, the lesion's color gradually turned dark blue-purple, almost black, and the shape changed to a firm and solid enlarged nodule, these findings led to the suspicion of a tumor. A skin biopsy was performed, and the patient's disease was finally diagnosed as JXG.

Neonatal systemic JXG is a rare disease, with only reported 32 cases in the literature (Table 1) [1, 2, 4-7, 9-32]. All cases

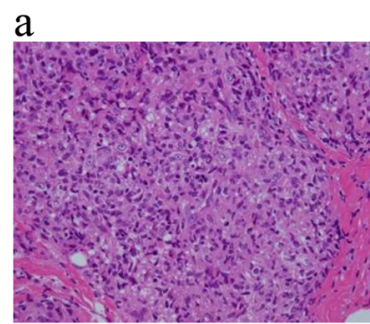

d

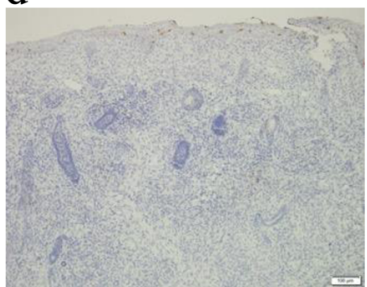

$\mathrm{b}$

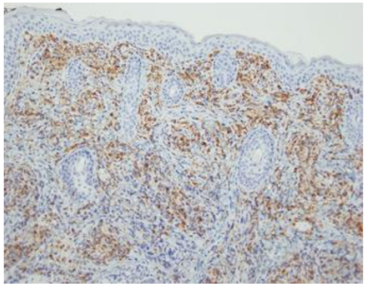

$\mathrm{e}$

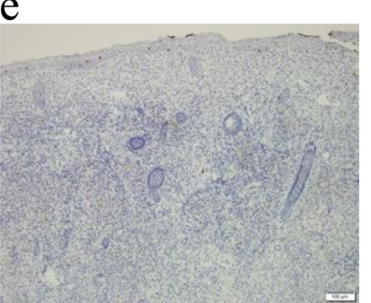

Fig. 3 Immunohistochemistry of the skin biopsy. It revealed the expression of CD68 and CD163 in the histiocytic population, whereas there was no expression of CD1a and Langerin. Hematoxylin and eosin staining showed an accumulation of histiocytes with several foamy cells $(\times 200$ magnification) (a). The immunohistochemical staining pattern of histiocytes was follows: CD68 positive (brown staining, $\times 100$ magnification) (b), CD163 positive (brown staining, $\times 100$ magnification) (c), CD1a negative (no brown staining, $\times 100$ magnification) (d), Langerin negative (no brown staining, $\times 100$ magnification) $(\mathbf{e})$ 
Table 1 Cases of neonatal systemic juvenile xanthogranuloma. We identified 33 cases of neonatal systemic juvenile xanthogranuloma, which included one or more affected visceral organs within the neonatal period, with the detailed case information

\begin{tabular}{|c|c|c|c|c|c|c|c|c|c|c|c|c|c|c|c|}
\hline \multirow{2}{*}{ Case $\mathrm{S}$} & \multirow{2}{*}{ Sex } & \multirow{2}{*}{ Age, days } & \multicolumn{2}{|c|}{ Skin lesions } & \multirow[b]{2}{*}{ Liver } & \multirow[b]{2}{*}{ Spleen } & \multirow[b]{2}{*}{ CNS 1} & \multicolumn{2}{|r|}{$\begin{array}{l}\text { Viceral organs } \\
\end{array}$} & \multicolumn{3}{|c|}{ Treatment } & \multirow{2}{*}{ Outcome } & \multirow[b]{2}{*}{ Notes } & \multirow[b]{2}{*}{ Reference } \\
\hline & & & First appearance & Changes over time & & & & Lungs & Others & Chemothrapy & Steroids & Others & & & \\
\hline 1 & м & 0 & ${ }^{*}$ Tan, yellow to red-brown papules and nodules & $\mathrm{NA}$ & + & + & . & - & - & $\mathrm{NA}$ & $\mathrm{NA}$ & $\mathrm{NA}$ & $\mathrm{NA}$ & & 14 \\
\hline 2 & $\mathrm{~F}$ & 0 & $\begin{array}{l}\text { *Multiple brownish } \\
\text { to reddish firm papules }\end{array}$ & $\mathrm{NA}$ & ${ }^{*+}$ & $*_{+}^{+}$ & - & ${ }^{*+}$ n & $\begin{array}{l}\text { Pancreas, adrenal gland, diaphragm, } \\
\text { mesenteric lymph nodes, mesentery, periadrenal fat }\end{array}$ & + & + & - & Death & Autopsy & 10 \\
\hline 3 & $\mathrm{~F}$ & 0 & Yellowish brown nodules & $\mathrm{NA}$ & $*+$ & - & - & ${ }^{*+}$ & $\begin{array}{l}\text { *Kidneys, *choroideal plexus, } \\
\text { *bone marrow }\end{array}$ & + & + & Radiotherapy & Death & Autopsy & 15 \\
\hline 4 & M & 0 & $\begin{array}{l}\text { *Typical, multiple } \\
\text { skin lesions }\end{array}$ & $\mathrm{NA}$ & + & + & - & - & - & + & + & SCT & Well & $\begin{array}{l}\text { With HLH } \\
\text { and JMML }\end{array}$ & 16 \\
\hline 5 & $\mathrm{~F}$ & 0 & $\begin{array}{l}\text { Pink and red papules, } \\
\text { *subcutaneous nodules }\end{array}$ & Disappearance & + & & - & + & - & - & - & - & Well & & 1 \\
\hline 6 & $\mathrm{~F}$ & 0 & $\begin{array}{l}{ }^{*} \text { "Reddish brown in color } \\
\text { with a irregular surfice }\end{array}$ & Flatter & + & - & & + & & & & - & Well & & 17 \\
\hline 7 & $\mathrm{~F}$ & 0 & $\begin{array}{l}\text { *Tan coloured papule, } \\
\text { *masses }\end{array}$ & Smaller & + & & - & + & - & - & - & - & Well & & 18 \\
\hline 8 & $\mathrm{~F}$ & 0 & $\begin{array}{l}\text { *Red nodule, } \\
\text { yellow-brown nodules }\end{array}$ & Disappearance & + & - & - & - & - & - & - & - & Well & 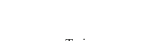 & . \\
\hline 9 & $\mathrm{~F}$ & 0 & *Yellow-brown nodules & Spontaneous regression & + & . & . & - & - & - & . & - & Well & Twins & 19 \\
\hline 10 & F & 0 & $\begin{array}{l}\text { *Reddish subcutaneous } \\
\text { solid mass }\end{array}$ & Petechiae $^{A}$ & + & + & - & - & - & + & - & - & Death & & 20 \\
\hline 11 & $\mathrm{~F}$ & 0 & $\begin{array}{l}\text { Erythematous and brownish } \\
\text { spots and papules }\end{array}$ & Petechiae $^{\wedge}$ & + & + & - & - & - & - & + & - & Well & Twin & 11 \\
\hline 12 & $\mathrm{~F}$ & 0 & $\begin{array}{l}\text { Erythematous and brownish } \\
\text { macules and papules }\end{array}$ & $\mathrm{NA}$ & $*_{+}$ & + & - & - & - & - & + & - & Well & Twins & 11 \\
\hline 13 & $\mathrm{M}$ & $3 w$ & $\begin{array}{l}\text { *Gray/blue, } \\
\text { tan/orange nodules }\end{array}$ & Subcutaneous nodules ${ }^{\wedge}$ & + & + & - & ${ }^{*+}$ & Kidneys, vertebra plana & + & + & - & Well & & 21 \\
\hline 14 & $\mathrm{M}$ & 0 & Petechiae & $\begin{array}{l}{ }^{*} \text { Erythematous papules }{ }^{A} \text { (flat or retracted } \\
\text { with a yellow-brown huc }{ }^{\mathrm{B}} \text { ) }\end{array}$ & $*+$ & + & - & - & - & + & + & - & Well & & 12 \\
\hline 15 & $\mathrm{M}$ & 1 & Spots & $\begin{array}{l}\text { "Enlarged, pale, } \\
\text { yellow-brown verrucous lesion }\end{array}$ & - & - & - & - & ${ }^{*}$ Heart & - & - & - & Well & & 22 \\
\hline 16 & $\mathrm{~F}$ & 0 & Skin eruption & $\begin{array}{l}\text { *Yellow-brown to erythematous } \\
\text { papules and nodules (blucberry muffin) }\end{array}$ & ${ }^{*}+$ & - & - & - & Bone & - & + & $\begin{array}{c}\text { LT, } \\
\text { immunosuppressant }\end{array}$ & Well & & 5 \\
\hline 17 & M & $\mathrm{Iw}$ & $\begin{array}{l}\text { *Slightly bluish nodules, } \\
\text { multiple, small, flesh-colored lesions }\end{array}$ & $\mathrm{NA}$ & $*_{+}$ & + & - & - & Soff tissue & + & + & - & well & Matemal UTI & 4 \\
\hline 18 & $\mathrm{~F}$ & 0 & $\begin{array}{l}\text { Ecchymosess, *dark red } \\
\text { subcutaneous mass, solid subcutaneou massses }\end{array}$ & $\mathrm{NA}$ & + & + & + & - & - & + & + & - & Well & & 6 \\
\hline 19 & $\mathrm{M}$ & 0 & $\begin{array}{c}\text { Petcchiac and purpura with } \\
*^{*} \text { a subcutaneous solid nodule }\end{array}$ & $\mathrm{NA}$ & + & + & - & - & *Placenta & + & + & - & Well & & 23 \\
\hline 20 & м & 0 & Petechial rash & $\mathrm{NA}$ & ${ }^{*+}$ & + & - & - & - & - & - & - & Well & $\begin{array}{l}\text { Osteopetrosisa mutation } \\
\text { in the PLEKHMI }\end{array}$ & 24 \\
\hline 21 & $\mathrm{~F}$ & 0 & *Bluish palpable nodular lesion & $\mathrm{NA}$ & ${ }^{*+}$ & ${ }^{*+}$ & - & - & $\begin{array}{l}\text { "Pancreas, *kidneys, *yymph nodes, } \\
\text { "pleura, "parasympathetic nodes }\end{array}$ & - & - & - & Death & Autopsy & 13 \\
\hline 22 & м & 0 & Blueberry muffin rash & ${ }^{* \text { Mass }^{A}}$ & + & + & - & + & Soft tissue, lymph node & + & + & - & Well & & 25 \\
\hline 23 & м & $4 \mathrm{w}$ & ${ }^{*}$ Blueberry muffin rash & Slowly improved ${ }^{\mathrm{B}}$ & + & + & . & + & - & + & + & - & Death & & 26 \\
\hline 24 & $\mathrm{~F}$ & 3 & ${ }^{*}$ Mass & Enlarged & + & - & - & - & Adrenal gland, bone & + & + & - & Well & $\begin{array}{l}\text { A left vocal cord paralysis } \\
\text { and left facial paralysis }\end{array}$ & 27 \\
\hline 25 & $\mathrm{NA}$ & 10 & *Subcutaneous nodules & Swelling & & + & - & ${ }^{*+}$ & ${ }^{* \text { Colon }}$ & + & + & - & Death & $\begin{array}{l}\text { Parents with } \\
\text { cross-cousin marriage }\end{array}$ & 28 \\
\hline 26 & $\mathrm{~F}$ & 10 & ${ }^{*}$ Nodules & Smaller & - & + & - & + & Retroperitoneal mass & - & - & Surgery & Well & & 29 \\
\hline 27 & M & $\mathrm{NB}$ & *Skin nodules & $\mathrm{NA}$ & *+ & + & - & - & - & $\mathrm{NA}$ & $\mathrm{NA}$ & $\mathrm{NA}$ & $\mathrm{NA}$ & & 30 \\
\hline 28 & $\mathrm{M}$ & 0 & $\begin{array}{l}\text { "Multiple cutaneous } \\
\text { and subutaneous lesions }\end{array}$ & $\mathrm{NA}$ & $*_{+}$ & + & - & + & - & $\mathrm{NA}$ & $\mathrm{NA}$ & $\mathrm{NA}$ & Death & Autopsy & 2 \\
\hline 29 & $\mathrm{~F}$ & 0 & *Skin lesions & $\mathrm{NA}$ & + & + & - & ${ }^{*+}$ & $\begin{array}{l}\text { *Heart, *diaphragm, *kidney, } \\
\text { "small and *large intestine, } \\
\text { "bone marrow }\end{array}$ & + & + & - & Death & & 7 \\
\hline 30 & м & 5 & Skin lesion (-) & Skin lesion (-) & - & - & ${ }^{*+}$ & - & - & + & - & Surgery & Well & Seizure & 31 \\
\hline 31 & $\mathrm{NA}$ & 10 & Skin lesion (-) & Skin lesion (-) & - & & - & - & "Heart & - & - & Surgery & Well & & 9 \\
\hline 32 & $\mathrm{NA}$ & $\mathrm{NB}$ & $\mathrm{NA}$ & $\mathrm{NA}$ & + & $\mathrm{NA}$ & $\mathrm{NA}$ & $\mathrm{NA}$ & $\mathrm{NA}$ & $\mathrm{NA}$ & $\mathrm{NA}$ & $\mathrm{NA}$ & $\mathrm{NA}$ & & 32 \\
\hline 33 & F & 0 & Purpura & $\begin{array}{l}\text { "Dark blue-purple firm } \\
\text { and solid enlarged nodule }\end{array}$ & + & + & - & - & - & + & + & - & Well & Fetal hydrops & Present case \\
\hline
\end{tabular}

listed in Table presented systemic symptoms or had at least one affected visceral organ within the neonatal period. JXG typically presents yellow to pink-brown papules and nodules; 16 of the 32 cases presented a typical color (such as yellow and erythematous) $[1,5,10-12,14-22]$, with three of the 16 cases subsequently changing to a typical color [5, 12, 22]. Eight cases had atypical skin lesions; one case had purpura (as in our case) [23], and the others had bluish nodules, ecchymoses, petechiae, blueberry muffin rash, and a mass [4, 6, 13, 23-27]. Six cases had unclear in the details $[2,7,28-30,32]$. There were nine cases $[5,11,12,20-22,25,27,28]$ in which the color and/or shape changed (excluding flattening, regression and disappearance) or new skin findings appeared over time, although there is a possibility that the change was not recognized because the patient was treated before the diagnosis. Change over time has been reported as a feature of congenital JXG [3]. Therefore, diagnosis by visual inspection is difficult because it involves various phenotypes such as color, 
shape, and changes over time. It is unclear why the emergence of congenital JXG differs from that of a typical JXG, but it has been speculated that neonatal skin has less subcutaneous fat and appears purple due to subcutaneous bleeding.

The liver biopsy could not clearly diagnose JXG. However, we considered the results consistent with a JXG lesion because the US and MRI findings showed that it had decreased after the chemotherapy. The diagnosis of JXG could not be made in four cases through a liver biopsy $[19,20,26]$, showing that liver biopsy can cause difficulties in revealing JXG and has a higher risk than skin biopsy. Congenital systemic JXG is therefore difficult to diagnose from the skin appearance.

The number of cells, including foamy histiocytes, in bone marrow aspiration after birth was too less to reveal an etiology.

When there are organ symptoms, abnormal liver findings, hydrops, and skin rash (even if the skin's appearance is not that of a typical yellow papule or nodule), congenital JXG should be actively suspected, and a skin biopsy should be performed.

\section{Abbreviations}

CNS: Central nervous system; HLH: Hemophagocytic lymphohistiocytosis; JMML: Juvenile myelomonocytic leukemia; JXG: Juvenile xanthogranuloma; LT: Liver transplantation; MRI: Magnetic resonance imaging; NA: Not available; NB: Newborn; SCT: Stem cell transplant; US: Ultrasound; UTI: Urinary tract infection; w: Week-old

\section{Acknowledgments}

We would like to thank Dr. Reiko Ito and Dr. Seisuke Sakamoto for helping in the diagnosis of JXG.

\section{Authors' contributions \\ $Y U, Y W, Y I 1, K Y 1, Y I 2, S A, H M, K T$, TI and YI3 cared for the patient. YU and YW drafted the manuscript and conducted the literature search. KS and YS supported the diagnosis and proposed the proper treatment. KY2 and NM performed the skin lesion biopsy. RI and TY performed the pathological diagnosis. OM helped diagnose of JXG from the images. All authors have read and approved the manuscript.}

\section{Funding}

No funds were needed to publish this case.

\section{Availability of data and materials}

The datasets supporting this article can be obtained upon request.

\section{Declarations}

Ethics approval and consent to participate

This study was approved by the Human Research Ethics Committee at the National Center for Child Health and Development, Tokyo, Japan.

\section{Consent for publication}

Written informed consent was obtained from the patient's parents for publication of this case report and the accompanying images. A copy of the written consent form is available for review by the editor-in-chief of this journal.

\section{Competing interests}

The authors declare that they have no competing interests.।

\section{Author details}

'Department of Neonatology, Center for Maternal-Fetal, Neonatal and Reproductive Medicine, National Center for Child Health and Development, 2-10-1 Okura, Setagaya-ku, Tokyo 157-8535, Japan. ${ }^{2}$ Chilldren's Cancer Center, National Center for Child Health and Development, 2-10-1 Okura, Setagaya-ku, Tokyo 157-8535, Japan. ${ }^{3}$ Department of Radiology, National Center for Child Health and Development, 2-10-1 Okura, Setagaya-ku, Tokyo 157-8535, Japan. ${ }^{4}$ Department of Clinical Pathology, National Center for Child Health and Development, 2-10-1 Okura, Setagaya-ku, Tokyo 157-8535, Japan. ${ }^{5}$ Department of Pathology, Nippon Koukan Hospital, 1-2-1 Koukandouri, Kawasaki-ku, Kawasaki City, Kanagawa 210-0852, Japan. ${ }^{6}$ Department of Dermatology, National Center for Child Health and Development, 2-10-1 Okura, Setagaya-ku, Tokyo 157-8535, Japan.

Received: 7 December 2020 Accepted: 28 March 2021

Published online: 06 April 2021

\section{References}

1. Diard F, Cadier L, Billaud C, Trojani M. Neonatal juvenile xanthogranulomatosis with pulmonary, extrapleural and hepatic involvement. One case report. Ann Radiol (Paris). 1982;25(2):113-8.

2. Dehner LP. Juvenile xanthogranulomas in the first two decades of life: a clinicopathologic study of 174 cases with cutaneous and extracutaneous manifestations. Am J Surg Pathol. 2003;27(5):579-93. https://doi.org/10.1097/ 00000478-200305000-00003.

3. Oza VS, Stringer T, Campbell C, Hinds B, Chamlin SL, Frieden IJ, et al. Congenital-type juvenile xanthogranuloma: a case series and literature review. Pediatr Dermatol. 2018;35(5):582-7. https://doi.org/10.1111/pde.13 544.

4. Freyer DR, Kennedy R, Bostrom BC, Kohut G, Dehner LP. Juvenile xanthogranuloma: forms of systemic disease and their clinical implications. $J$ Pediatr. 1996;129(2):227-37. https://doi.org/10.1016/50022-3476(96)70247-0.

5. Haughton AM, Horii KA, Shao L, Daniel J, Nopper AJ. Disseminated juvenile xanthogranulomatosis in a newborn resulting in liver transplantation. J Am Acad Dermatol. 2008;58(2):S12-5. https://doi.org/10.1016/j.jaad.2007.09.012.

6. Nakatani T, Morimoto A, Kato R, Tokuda S, Sugimoto T, Tokiwa K, et al. Successful treatment of congenital systemic juvenile xanthogranuloma with Langerhans cell histiocytosis-based chemotherapy. J Pediatr Hematol Oncol. 2004;26(6):371-4. https://doi.org/10.1097/00043426-200406000-00007.

7. Janssen D, Harms D. Juvenile xanthogranuloma in childhood and adolescence: a clinicopathologic study of 129 patients from the Kiel pediatric tumor registry. Am J Surg Pathol. 2005;29(1):21-8. https://doi.org/1 0.1097/01.pas.0000147395.01229.06.

8. Morimoto A, Shioda Y, Imamura T, Kudo K, Kawaguchi H, Sakashita K, et al. Intensified and prolonged therapy comprising cytarabine, vincristine and prednisolone improves outcome in patients with multisystem Langerhans cell histiocytosis: results of the Japan Langerhans cell Histiocytosis study Group-02 protocol study. Int J Hematol. 2016;104(1):99-109. https://doi. org/10.1007/s12185-016-1993-3.

9. Malcic I, Novick WM, Dasovic-Buljevic A, Jelasic D, Jelusic M, Kniewald H. Intracardiac juvenile xanthogranuloma in a newborn. Pediatr Cardiol. 2001; 22(2):150-2. https://doi.org/10.1007/s002460010183.

10. Hu WK, Gilliam AC, Wiersma SR, Dahms BB. Fatal congenital systemic juvenile xanthogranuloma with liver failure. Pediatr Dev Pathol. 2004;7(1): 71-6. https://doi.org/10.1007/s10024-003-4040-3.

11. Chantorn R, Wisuthsarewong W, Aanpreung P, Sanpakit K, Manonukul J. Severe congenital systemic juvenile xanthogranuloma in monozygotic twins. Pediatr Dermatol. 2008;25(4):470-3. https://doi.org/10.1111/j.1525-14 70.2008.00752.x

12. Papadakis V, Volonaki E, Katsibardi K, Stefanaki K, Valari M, Anagnostakou M, et al. A rare case of neonatal systemic xanthogranulomatosis with severe hepatic disease and metachronous skin involvement. J Pediatr Hematol Oncol. 2012;34(3):226-8. https://doi.org/10.1097/MPH.0b013e3182203086.

13. Rodriguez-Velasco A, Rodriguez-Zepeda MDC, Ortiz-Hidalgo C. Infantile systemic juvenile xanthogranuloma case with massive liver infiltration. Autops Case Rep. 2019;9(2):e2018081. https://doi.org/10.4322/acr.2018.081.

14. Sangueza OP, Salmon JK, White CR Jr, Beckstead JH. Juvenile xanthogranuloma: a clinical, histopathologic and immunohistochemical study. J Cutan Pathol. 1995;22(4):327-35. https://doi.org/10.1111/j.16000560.1995.tb01415.x. 
15. Azorin D, Torrelo A, Lassaletta A, de Prada I, Colmenero I, Contra T, et al. Systemic juvenile xanthogranuloma with fatal outcome. Pediatr Dermatol. 2009;26(6):709-12. https://doi.org/10.1111/j.1525-1470.2009.01018.x.

16. Arachchillage DRJ, Carr TF, Kerr B, Hawkins K, Kelsey A, Judge M, et al. Juvenile myelomonocytic leukemia presenting with features of neonatal hemophagocytic lymphohistiocytosis and cutaneous juvenile xanthogranulomata and successfully treated with allogeneic hemopoietic stem cell transplant. J Pediatr Hematol Oncol. 2010;32(2):152-5. https://doi. org/10.1097/MPH.0b013e3181cf4575.

17. Cusick EL, Spicer RD. Juvenile xanthogranuloma with extra-cutaneous lesions--a case report. Eur J Pediatr Surg. 1994;4(06):368-9. https://doi.org/1 0.1055/s-2008-1066137.

18. Guthrie JA, Arthur RJ. Case report: juvenile xanthogranuloma with pulmonary, subcutaneous and hepatic involvement. Clin Radiol. 1994;49(7): 498-500. https://doi.org/10.1016/50009-9260(05)81751-9.

19. Kobayashi K, Imai T, Adachi S, Yoifuji T, Furusho K, Kore-eda S, et al. Juvenile xanthogranuloma with hematologic changes in dizygotic twins: report of two newborn infants. Pediatr Dermatol. 1998;15(3):203-6. https://doi.org/1 0.1046/j.1525-1470.1998.1998015203.x

20. De Santiago J, Martinez-Garcia E, Giron J, Salcedo C, Perez-Gallardo A. Prophylactic recombinant factor VIla administration to an infant with congenital systemic juvenile xanthogranuloma. Paediatr Anaesth. 2006;16(9): 974-6. https://doi.org/10.1111/j.1460-9592.2006.02009.x.

21. Patel P, Vyas R, Blickman J, Katzman P. Multi-modality imaging findings of disseminated juvenile xanthogranuloma with renal involvement in an infant. Pediatr Radiol. 2010:40(Suppl 1):S6-10.

22. Pois AJ, Johnson LA. Multiple congenital xanthogranulomas of skin and heart. Report of a case. Dis Chest. 1966;50(3):325-9. https://doi.org/10.1378/ chest.50.3.325.

23. Takeuchi M, Nakayama M, Nakano A, Kitajima H, Sawada A. Congenital systemic juvenile xanthogranuloma with placental lesion. Pediatr Int. 2009; 51(6):833-6. https://doi.org/10.1111/j.1442-200X.2009.02932.x.

24. Almarzoogi S, Reed S, Fung B, Boué DR, Prasad V, Pietryga D. Infantile osteopetrosis and juvenile xanthogranuloma presenting together in a newborn: a case report and literature review. Pediatr Dev Pathol. 2011;14(4): 307-12. https://doi.org/10.2350/10-09-0909-CR.1.

25. Fan R, Sun J. Neonatal systemic juvenile xanthogranuloma with an ominous presentation and successful treatment. Clin Med Insights Oncol. 2011;5:15761. https://doi.org/10.4137/CMO.S6686.

26. Mudambi K, Berquist W. "Blueberry muffin" rash and neonatal cholestatic liver failure. Dig Dis Sci. 2018;63(7):1747-50. https://doi.org/10.1007/s10620017-4810-9.

27. Eggli KD, Caro P, Quiogue T, Boal DK. Juvenile xanthogranuloma: non-X histiocytosis with systemic involvement. Pediatr Radiol. 1992;22(5):374-6. https://doi.org/10.1007/BF02016261.

28. Nacaroglu HT, Can D, Unsal Karkiner CS, Yaman Y, Alper H, Tosun Yildirim H, et al. Baby with neonatal systemic juvenile xanthogranuloma born within a cross-cousin marriage. Dermatol Sin. 2015;33(4):231-3. https://doi.org/10.101 6/j.dsi.2015.01.001.

29. Garcia-Peña P, Mariscal A, Abellan C, Zuasnabar A, Lucaya J. Juvenile xanthogranuloma with extracutaneous lesions. Pediatr Radiol. 1992;22: 377-8.

30. Favara BE. Histopathology of the liver in histiocytosis syndromes. Pediatr Pathol Lab Med. 1996;16(3):413-33. https://doi.org/10.1080/155138196091 68681.

31. Gressot LV, Patel AJ, Bollo RJ, Mohila CA, Jea A. Disseminated intracranial juvenile xanthogranulomatosis in a neonate without cutaneous lesions. J Neurosurg Pediatr. 2013;12(2):187-91. https://doi.org/10.3171/2013.5. PEDS1332

32. Johnson K, Alton HM, Chapman S. Evaluation of mebrofenin hepatoscintigraphy in neonatal-onset jaundice. Pediatr Radiol. 1998:28(12): 937-41. https://doi.org/10.1007/s002470050505.

\section{Publisher's Note}

Springer Nature remains neutral with regard to jurisdictional claims in published maps and institutional affiliations.

\section{Ready to submit your research? Choose BMC and benefit from:}

- fast, convenient online submission

- thorough peer review by experienced researchers in your field

- rapid publication on acceptance

- support for research data, including large and complex data types

- gold Open Access which fosters wider collaboration and increased citations

- maximum visibility for your research: over $100 \mathrm{M}$ website views per year

At BMC, research is always in progress.

Learn more biomedcentral.com/submissions 